\title{
O ASSENTAMENTO COMO TERRA DE MISSÃO: RELIGIÃO E PROCESSOS DE TERRITORIALIZAÇÃO DOS SEM-TERRA NO RIO GRANDE DO SUL, BRASIL
}

\author{
RURAL SETTLEMENTS AS MISSION EARTH: \\ RELIGION AND PROCESSES FOR THE TERRITORIALI- \\ ZATION OF THE LANDLESS IN RIO GRANDE DO SUL, BRAZIL
}

Valter Lúcio de Oliveira ${ }^{1}$

RESUMO: É comum que os sem-terra se vejam obrigados a percorrerem longos percursos até serem assentados, em grande parte dos casos, distantes de seus locais de origem. Tendo isso em vista, neste artigo é analisado o processo de territorialização que se efetua nos assentamentos rurais, centrando o olhar em sua dinâmica religiosa. Notou-se que, ao se estabelecerem nesse novo local, as famílias buscam promover os ajustes necessários para concretizar novas relações sociais e criar as condições para a constituição de sua comunidade religiosa, tomando como referência as experiências trazidas de seus locais de origem. Esse processo produz situações de crises, disputas e conflitos, especialmente devido à diversidade social e religiosa que se concentra no local de chegada. A partir de tais análises, pretende-se expor a complexidade das relações sociais que se constituem nesses espaços, bem como averiguar o lugar ocupado pela questão religiosa e, dessa forma, compreender o processo de atribuição de sentidos e funções a esse novo território conquistado. As informações aqui analisadas estão baseadas em pesquisa empírica realizada em um acampamento e dois assentamentos, um de formação recente (quatro anos) e outro de formação mais antiga (15 anos), ambos organizados pelo Movimento dos Trabalhadores Sem Terra (MST) e localizados no Rio Grande do Sul.

Palavras-chave: MST, territorialização, comunidade, religião, nomadismo.

\footnotetext{
${ }^{1}$ Professor adjunto do Departamento de Sociologia e Metodologia em Ciências Sociais da Universidade Federal Fluminense (UFF). Professor do Programa de Pós-Graduação em Sociologia da Universidade Federal Fluminense (UFF), Niterói, RJ, Brasil, e-mail: valterlu@yahoo.com.br.
} 
ABSTRACT: It is common that the landless are forced to roam long distances until they are seated, in most cases, far from their places of origin. Considering this observation, in this paper, we analyze the process of territorialization that takes place in rural settlements centering the look on his religious dynamics. It was noted that when establishing this new location, families seek to promote the necessary adjustments to achieve new social relations and create the conditions for the establishment of a religious community, taking as reference the experiences brought from their places of origin. This produces situations of crises, conflicts and disputes account of the social and religious diversity that focus on the place of arrival. When performing such analyzes intended to expose the complexity of that effective social relations in these spaces, as well as analyze the role played by the religious question, and thus understand the process of assigning meanings and functions of this new territory conquered. The information discussed here is based on empirical research conducted in a camp and two settlements, one recent training (4 years) and other older formation (15 years), both organized by the MST and located in Rio Grande do Sul.

Keywords: MST, territorialization, community, religion, nomadism.

\section{INTRODUÇÃO}

As principais formas de ação do Movimento dos Trabalhadores Rurais Sem Terra (MST) são as ocupações de grandes propriedades e a constituição de acampamentos de sem-terra. Visam, com essas e outras ações, pressionar o poder público a efetivar desapropriações de terras e a realizar o assentamento das famílias que integram o MST.

Para atingir seus objetivos, no entanto, é necessário que realizem um constante deslocamento territorial durante um longo período de tempo, já que os latifúndios considerados passíveis de serem desapropriados podem estar muito distantes do local de origem dos sem-terra. Não ficar estacionado no mesmo local também constitui uma ação tática que compõe o seu repertório de ações. Da incorpora- 
ção ao MST até a conquista de um lote de terra, uma pessoa pode enfrentar mais de cinco anos de "luta" e percorrer mais de $2000 \mathrm{~km}$. Tal situação faz com que seja recorrente a constituição de assentamentos bastante distantes e distintos do local de origem dos sem-terra. Em função desse formato de "luta", os sem-terra acabam incorporando uma dinâmica nômade, no seu duplo sentido: objetivo e subjetivo. Objetivo devido aos constantes deslocamentos e subjetivo devido ao novo processo de reflexividade que essas pessoas experimentam.

Relacionado a essa dinâmica, que define grande parte das características do MST, está o fato de que, desde sua origem, esse movimento recebeu um ostensivo apoio de agentes religiosos (especialmente católicos) que, embora, seja menos evidente atualmente, ainda exerce influência no seu formato organizativo. Sintomático dessa influência são as frequentes realizações do que denominam "místicas". "Mística" é um tipo de ritual que tem um sentido e um formato marcadamente religioso, ainda que dotado de uma carga política muito mais evidente. Nessas "místicas", é comum a construção do paralelo entre as histórias bíblicas e a luta que empreendem. Apesar dessa influência religiosa, no acampamento pesquisado não é permitido o estabelecimento formal de expressões religiosas. O MST estabelece, como regra, o princípio do ecumenismo, e suas lideranças incumbem-se de organizar as celebrações com tal caráter. Esse tipo de regramento somente é possível no espaço do acampamento, pois é onde o controle de tais expressões e de certos comportamentos pode ser exercido com relativa facilidade. Já no assentamento, esse controle é precário e a diversidade ganha maior vazão. Assim, uma vez assentados, os sem-terra buscam reproduzir nesse novo espaço o formato da adesão religiosa que trazem do local de origem. O princípio do ecumenismo é, então, abandonado.

Ocorre que, em função de ser uma área recentemente povoada e habitada com um público proveniente de várias regiões, o assentamento torna-se uma "terra de missões", um local a ser conquistado pelas mais diversas formações religiosas. Nesse sentido, tais formações se fazem presente e disputam entre si os fiéis ali assentados. É possível verificar, ao menos temporariamente, um significativo trân- 
sito religioso. Fica evidente, também, que o espaço da religião passa a ser um importante espaço de sociabilidade e de adaptação ao novo ambiente social, constituindo, assim, uma dimensão importante na construção do novo território.

O conceito de território aqui referido designa a conjunção, no espaço, entre o material e o simbólico. O território constitui-se enquanto tal à medida que podem ser apreendidas essas dimensões (material e simbólica) em um mesmo espaço. Como salientado por Haesbaert (2008, p. 21), "todo território é, ao mesmo tempo e obrigatoriamente, em diferentes combinações, funcional e simbólico, pois exercemos domínio sobre o espaço tanto para realizar 'funções' quanto para produzir 'significados"'. O processo de territorialização, portanto, realiza-se à medida que se promove a apropriação e se exerce o domínio do espaço, atribuindo-lhe funções e significados.

Nesse sentido, um elemento importante no processo de territorialização são os esforços despendidos pelas famílias para constituírem sua comunidade religiosa. Assim, a partir dessa dinâmica que leva as famílias a se estabelecerem distantes de sua origem social e territorial, a dimensão religiosa é uma das dimensões significativas desse processo de territorialização.

Portanto, o foco deste artigo não consiste nos implicantes gerais determinados por essa dinâmica de "desterritorialização" que a luta pela terra impõe. O que será analisado é o processo de "reterritorialização" a partir de uma de suas dimensões específicas, mas central, que é definida pela religião e que também envolve militância política e migração. Isso será feito com base em pesquisa empírica, realizada ao longo de oito meses em um acampamento e em dois assentamentos (um recente, criado há quatro anos, e outro antigo, criado há 15 anos), localizados no estado do Rio Grande do Sul, Brasil. Esses distintos espaços possuem como característica unificadora o fato de serem organizados ou influenciados pelo MST. 


\section{CARACTERIZAÇÃO EMPÍRICA}

\subsection{O acampamento}

O acampamento pesquisado segue a estrutura paradigmática comum aos acampamentos organizados pelo MST: um conjunto de barracos de lona plástica preta, localizados normalmente em terrenos às margens das rodovias. Essa é a "marca registrada" dos acampamentos e tornou-se o símbolo do MST. É uma forma pouco custosa de se estabelecerem rápida e provisoriamente: tanto a chegada quanto a saída se dão sem grandes obstáculos.

A organização espacial do acampamento pesquisado é pensada para que exista apenas um lugar de entrada ou saída, fato facilitado pela vegetação e pela conformação física do terreno. Nesse local, está instalada uma guarita e uma cancela na qual sempre ( 24 horas por dia) há uma ou mais pessoas responsáveis pelo controle de quem entre ou sai. Para o acampado se ausentar do acampamento, ele deve apresentar ao responsável pela supervisão da guarita, tanto na saída quanto na entrada, uma pequena ficha padronizada em que consta a autorização para se ausentar do acampamento e o período previsto para tal. Para a entrada de um simples visitante, como era o meu caso, era necessária a indicação de alguma referência interna que seria consultada, a qual, se fosse o caso, autorizaria a entrada. Depois de certo período de visitas e estadia no acampamento, eu não tive mais necessidade dessa autorização, uma vez que as pessoas já tinham se habituado à minha presença e permitiam minha entrada sem tal consulta.

A chegada de alguém interessado em compor o acampamento ocorre de diferentes formas. A mais frequente é aquela impulsionada pelo trabalho da Frente de Massa (FM), isto é, indivíduos abordados por militantes do MST especialmente designados à tarefa de conquistar novos adeptos. Outra forma bastante comum consiste na chegada de pessoas a partir de convites de familiares e amigos já acampados ou assentados. Normalmente, o que ocorre é a conjunção dessas duas formas. Aquelas pessoas com referências familiares ou amicais que possuem alguma relação com o MST são alvos mais 
permeáveis ao convencimento por parte da FM. Também existem aqueles que, após saber da possibilidade de "ganhar terra" por meio do Movimento, decidem aderir espontaneamente. No acampamento pesquisado, este perfil ocorria com maior frequência em função de estar localizado nos arredores de grandes centros urbanos.

Existia, também, a presença de acampados provenientes de outros acampamentos, que ocorria quando vinham de um acampamento que havia se extinguido em função do assentamento de parte de seus integrantes, quando eram vítimas de despejo ou quando queriam fortalecer um único acampamento. Essa movimentação também se insere na lógica da mobilização, já que um acampamento, para cumprir com sua função, nunca deve permanecer por muito tempo em um único local, pois do contrário, não tornaria visíveis as suas reivindicações.

A atuação da Frente de Massa mudou significativamente com o passar do tempo. Nos primeiros anos do MST, as reuniões organizadas pela FM eram realizadas em salões comunitários, em igrejas do meio rural ou mesmo do meio urbano de pequenos municípios, em sindicatos de trabalhadores rurais ou, ainda, em espaços improvisados, invariavelmente em cidades do interior do estado. A difusão do Movimento entre os camponeses acontecia a partir desses espaços organizativos já estabelecidos, e o processo de convencimento ocorria, majoritariamente, de forma coletiva e apoiado por outros agentes, especialmente aqueles vinculados às igrejas e aos sindicatos. Ainda que atualmente ocorram reuniões com o objetivo de apresentar a opção do acampamento a grupos de potenciais interessados, o que tem sido mais recorrente na atuação da FM é um tipo de abordagem individual ou familiar visando àqueles que habitam as "vilas" ${ }^{2}$. Visam, também, àqueles que habitam as ruas: "estava em Porto Alegre, vi um garoto de rua e chamei ele pra vir acampar”, comentou uma liderança.

\footnotetext{
${ }^{2}$ Como também salientado por Caballeiro (2008, p.17), o termo "vila" assume no contexto regional um sentido pejorativo, sendo sinônimo do que em outros lugares se denomina "favela". Essa explicação também me foi dada por uma acampada evangélica. Ao se referir à parte das pessoas do acampamento como "vileiros" e ao notar que eu não compreendia bem o sentido daquela denominação, esboçou uma expressão facial, visando demonstrar que se tratava de pessoas com baixa reputação social, e me explicou verbalmente que eram o que em outros lugares se chamam de favelados. Ao falar dos "vileiros", ela usava uma expressão estigmatizadora para situar sua família a certa distância daquele tipo de público.
} 
A unidade social de referência no acampamento é a família. Sempre irão utilizar a família como parâmetro para referirem-se aos que pertencem ao acampamento, mesmo que boa parte chegue e se estabeleça ali de forma individual. Tal tratamento se deve ao fato de que, mesmo naqueles casos em que a família não se junta ao acampado no acampamento, está pressuposto que o acompanhará para o assentamento. Como se verificou, a ida para o assentamento pode significar, inclusive, a re-unificação familiar. Conheci várias pessoas que disseram que não iriam para um assentamento muito distante para não se afastar da família, como foi o caso de uma senhora com três filhos pequenos que havia sido selecionada para ser assentada em uma região que distava cerca de $400 \mathrm{~km}$ do acampamento onde estava, mas havia renunciado à vaga, dizendo que seus familiares não estavam dispostos a acompanhá-la e ela se sentia insegura para gerir o lote sozinha.

A família constitui aquilo que, na linguagem corrente entre os acampados, chama-se de "base". O sentido de "base", nesse caso, é bem distinto daquele da linguagem militante, em que o termo base é entendido como o antônimo de dirigente, isto é, designa aquele grupo social que dá sustentação às ações dos dirigentes. Já o sentido adotado pelas pessoas do acampamento refere-se ao local e ao meio social de onde o acampado é proveniente. Em uma de minhas primeiras visitas ao acampamento, um garoto de 13 anos foi logo me perguntando: “como está a base?". Imediatamente associei a pergunta à base do MST, como se tivesse me perguntado: "como está o movimento em outros lugares?". Imaginava, com isso, que ele estava supondo minha pertença aos quadros do MST. Baseado naquilo que concebia como "base", fiquei surpreendido com aquela abordagem e logo imaginei: "olha o grau de politização desse garoto, tão novo e já se interessa pelos assuntos do Movimento”. Apenas mais tarde, fui me dando conta de que a expressão era usual entre os acampados e indicava a relação que possuíam com o local de proveniência de cada pessoa que estava ali: "vou voltar pra minha base", "vou visitar a minha base" e "como está a sua base?" eram expressões comuns. Dessa forma, ficava claro que contavam com uma base familiar ou comunitária a que estavam vinculados e da qual provinha o apoio 
moral e material para permanecerem ali. Portanto, base era a palavra que sintetizava o vínculo dos indivíduos com seus locais de origem e, ao mesmo tempo, era o sinal de vinculação entre estes espaços mais gerais: a comunidade externa e a comunidade do acampamento. Ambos os lugares produziam sociabilidades diferentes, que se interpenetravam por meio dos indivíduos que mantinham esse duplo vínculo. Esse é um importante aspecto a ser considerado, pois as pessoas que estão ali no acampamento trazem consigo outras dimensões de sua vida. Nesse sentido, como bem salienta Quirós (2006, p.27) em seu estudo sobre os Piqueteros organizados nos subúrbios de Buenos Aires, Argentina, deve-se "partir del pressupuesto de que la vida tiene otras dimensiones a través de las cuales el formar parte de um movimiento puede tornarse más inteligible”.

Uma vez estabelecido no acampamento, todo indivíduo é imediatamente alocado em um Setor de Trabalho e em um Núcleo de Base (NB). Base, nesse caso, já é uma categoria proveniente do vocabulário militante e designa a instância organizativa mais elementar do acampamento a partir da qual emana a legitimação para graus mais elevados na hierarquia do Movimento. De cada um desses núcleos, destacam-se dois coordenadores (preferencialmente um homem e uma mulher) para representá-los nas instâncias superiores. Esse "destaque" ocorre tanto no que se refere a tornar-se visível a partir da distinção em termos de capital militante (oratória, liderança e capital político) quanto no sentido de ir além da base e do próprio acampamento para avançar sobre outros espaços de poder dentro da estrutura do MST.

As participações nos NBs e nos Setores de Trabalho são obrigatórias. Trata-se, juntamente com a participação nas suas lutas ${ }^{3}$, das únicas contrapartidas exigidas formalmente para integrar o acampamento e, sobretudo, manter-se elegível como um possível assentado ${ }^{4}$. As lutas, nesse caso, são as suas manifestações, ocupações, marchas etc. A parti-

\footnotetext{
${ }^{3}$ Sobre os vários sentidos da categoria "luta", ver Comerford (1999). Conferir as análises realizadas por esse mesmo autor concernentes à sociabilidade agonística em comunidades do interior de Minas Gerais em Comerford (2003).

${ }^{4}$ Os critérios que são levados em conta no processo de seleção para a conquista de um lote em um assentamento organizado pelo MST são: tempo de acampamento e participação nas lutas. Caso o acampado não se interesse por aquela área, ele pode permanecer no acampamento até surgir nova possibilidade.
} 
cipação nas lutas é como um ritual iniciático. Todo acampado é iniciado em um processo de identificação do inimigo e de autoidentificação como sem-terra e passa a compreender as relações sociais a partir de um sentido agonístico muito importante nos discursos e nas ações do MST. Nesse contexto, ressaltam-se as análises de Thompson (1987), ao observar que não existe a classe antes da luta de classes. Deve ser considerado que é a partir da experiência que os agentes aqui analisados "aprenderam a ver suas vidas como parte de uma história geral de conflitos" (p. 304) e assim se constituíram como agentes em lutas.

A diversidade de participação da (e na) base é bastante grande, o que permite o envolvimento de todos acampados a partir de suas mais diversas aptidões ${ }^{5}$. Obviamente que, mesmo entre os espaços de participação da "base", há certas atividades mais "nobres" e que exigem maior qualificação, ao menos de uma parcela de seus integrantes, como é o caso da equipe de educação e das finanças. A estrutura organizativa do acampamento é composta, em linhas gerais, pelas seguintes instâncias:

1. Brigada de Organicidade (BO)

2. Frente de Massa (FM)

3. Coordenação do Acampamento

4. Núcleo de Base (NB)

5. Setores de Trabalho:

- Setor da Secretaria

- Setor da Comunicação

- Setor da Infraestrutura

- Setor dos Direitos Humanos

- Setor da Agitação e Propaganda (AGITPROP)

- Setor da Educação

- Setor da Saúde

- Setor das Finanças.

\footnotetext{
${ }^{5}$ Citando a fala de um marchante, Chaves (2000, p.305) também destaca esse aspecto: “"no MST você resgata o indivíduo. Não precisa se uniformizar. No mst você pode ser você mesmo. Se é músico, trabalha com música; se gosta de falar com o povo, faz discurso; se é professor, ensina. Toda contribuição é bem vinda e você pode contribuir com o que sabe'. No MST diz-se que 'o coletivo educa', e os individuos que nele se integram costumam crer que nele realizam suas melhores qualidades, apesar de incontáveis vezes deverem subordinar-se às 'decisões do coletivo'. Com essa hierarquia, a dinâmica entre individuo e coletividade é vista no MST sob um aspecto positivo".
} 
Figura 1. Organograma da estrutura organizativa do acampamento

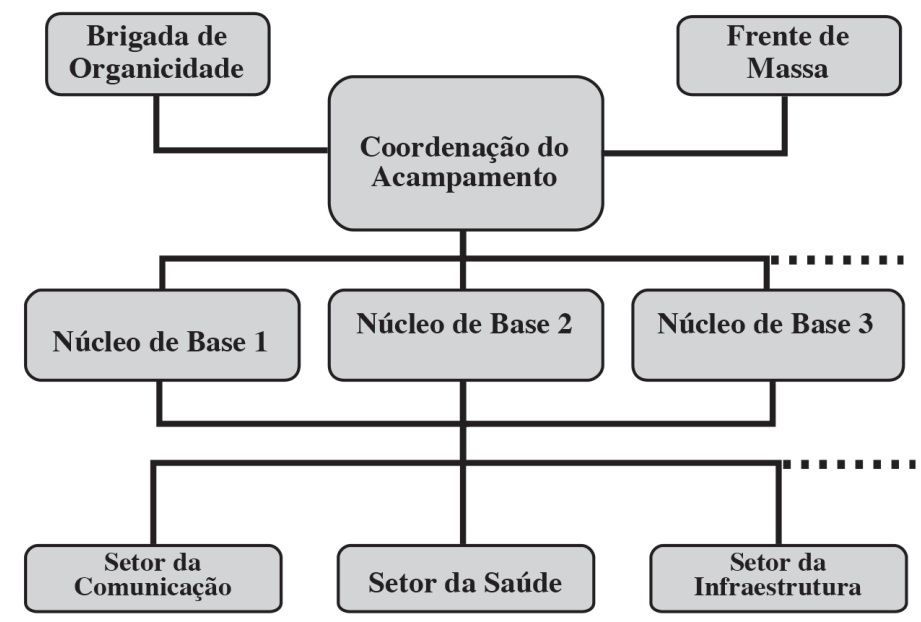

\subsection{0 assentamento novo}

Abrigando 102 famílias, ele foi criado sobre uma área de 1600 hectares que vinha enfrentando um longo processo judicial em função do endividamento de seus donos. As famílias que ali chegaram vinham de seis acampamentos diferentes. Apesar disso, a classificação que foi, de fato, estabelecida entre eles referia-se aos oriundos da região central do estado, mais interiorana e vinculada mais diretamente à atividade agrícola, e os oriundos da região próxima à capital, em sua maioria provenientes das "vilas". A área onde hoje estão assentados pertencia a uma empresa de previdência privada que, ao falir, teve todos os seus bens confiscados pela justiça.

Uma característica importante desse assentamento é que ele está localizado bastante próximo ao perímetro urbano do município ao qual pertence e de outros municípios maiores e mais urbanizados. Esse fato cria uma situação delicada na relação interna entre os que trabalhavam "fora" e aqueles considerados legitimamente agricultores. No caso dos que conseguiam emprego na cidade, eles tentavam promover um ajuste entre o trabalho agrícola realizado no lote e o 
emprego urbano. As atividades urbanas que foram mais frequentemente relatadas pelos assentados são: balconista, garçom, frentista, cozinheira, atendente de supermercado, empregada doméstica (diarista) e empregado industrial. No entanto, o assalariamento urbano constituía-se em um ponto nevrálgico da convivência entre os assentados. Eram promovidas constantes acusações contra aqueles que trabalhavam fora. Essas acusações se davam tanto na forma direta quanto indireta. Nas reuniões da coordenação, eram casos abordados e criticados e, na convivência cotidiana, constituíam alvo de algumas insinuações irônicas e estigmatizadoras, tais como "fulano de tal pode emprestar dinheiro, pois tem um bom emprego na cidade”.

O formato organizativo desse assentamento era muito similar ao que vigorava nos acampamentos. Havia a direção do assentamento, a coordenação e os bolsões, que se aproximariam, respectivamente, do que são a BO, a Coordenação e o NB do acampamento. Nesse assentamento, não se consolidou nenhum grupo de produção coletiva nem associações de máquinas e de trabalho. Como se trata de um assentamento recente, isso ainda pode ocorrer.

Os assuntos principais que, durante essa fase inicial, mobilizam os assentados a partir dessa estrutura organizativa, estão relacionados com as questões mais urgentes: os créditos a que terão direitos, a negociação coletiva do arrendamento ${ }^{6}$ de parte de seus lotes para a produção do arroz (principal aptidão de suas áreas), as melhorias das estradas do assentamento, a construção da igreja, os problemas com as divisas dos lotes etc. Mesmo que no acampamento as questões práticas fossem também as que mais mobilizavam os acampados, ali havia, ao menos, vários momentos coletivos voltados para a mística do Movimento e para a formação política. No assentamento, essas dimensões eram praticamente inexistentes, ficando concentradas apenas nos militantes mais fiéis que viviam o MST no seu cotidiano e, por isso, estavam em constante contato com os momentos de lutas mais intensas que são, por sua natureza, reforçadoras da identidade e da mística do "ser" sem-terra. Mas isso não significa

\footnotetext{
${ }^{6}$ Apesar de proibido, o arrendamento foi a única alternativa que encontraram para produzir arroz na parte de seus lotes propícia a essa produção. Como se trata de uma cultura muito custosa e exigente em termos de tecnologia, os assentados não possuíam recursos nem conhecimento para tal.
} 
que não havia no assentamento um reconhecimento individual do MST ou mesmo uma postura pessoal que renunciasse ao seu passado de lutas. Não encontrei nenhum caso que desprezasse o Movimento, mesmo que alguns tecessem fortes críticas a certos militantes e aos rumos que atribuíam ao MST. Em geral, essa vinculação com o Movimento se expressava na forma de gratidão e fidelidade.

\subsection{0 assentamento antigo}

O segundo assentamento pesquisado, bem mais antigo, foi criado há 15 anos e está localizado a aproximadamente dez quilômetros de distância do assentamento novo. Conta com aproximadamente 2000 hectares e abriga 100 famílias. Dessas, 30 estão organizadas no formato de Cooperativa de Produção Agrícola (CPA) e 70 produzem individualmente. Entre estas, há a formação de associações voltadas especialmente para a compra e o uso de maquinário. Como no assentamento novo, neste também a produção de arroz é a principal atividade agrícola. Contam com uma área propícia à produção de arroz irrigado e outra área que é utilizada para culturas de sequeiro.

A fazenda na qual foram assentados foi desapropriada oficialmente em maio de 1994. Conforme relatos, o seu antigo dono havia contraído uma enorme dívida com o objetivo de construir uma usina para produção de álcool; no entanto, esse recurso foi desviado para outros fins e tal empreendimento não foi realizado. Como não honrou sua dívida, toda a fazenda foi confiscada pelo Banco do Brasil. Da mesma forma que no assentamento novo, iniciou-se um longo processo judicial. Em 1987, o MST a ocupou pela primeira vez. Após determinado período, as famílias ocupantes foram expulsas daquela área, mas lograram ser assentadas em outra área próxima dali. Em 1993, ocorreu nova ocupação, e, dessa vez, os acampados saíram vitoriosos.

Ao chegar nesse assentamento, o que se destaca com relação ao assentamento novo é, naturalmente, a quantidade de benfeitorias existentes, com aparência de sítios já consolidados. Notam-se casas de alvenaria ou de madeira, árvores frutíferas e ornamentais, jardins, galpões, porteiras na entrada da propriedade, enfim, fatores 
que ressaltam a marca do tempo. No caso da cooperativa, esse aspecto é ainda mais explícito. A rua que liga a estrada principal à sede da cooperativa (que também era a sede da antiga fazenda) é ladeada por enormes galpões e por estruturas de produção e beneficiamento.

Os cooperados habitam, em sua maioria, na agrovila. A agrovila é uma configuração de residências dispostas uma ao lado da outra, formando um enorme "retângulo". Cada família que mora ali tem um pequeno lote de terra onde constrói suas casas, cria pequenos animais e faz suas hortas. Geograficamente, a agrovila situa-se na crista de uma elevação, que está no centro do assentamento.

\subsection{O nomadismo objetivo e subjetivo na longa marcha rumo à conquista da terra}

\section{Pergunta: Como foi o tempo de acampamento?}

Resposta: Ah, isso foi muita dificuldade, mas muita vitória também. Momentos bons, momentos ruins. Hoje quem vai acampar não sabe quando vai ganhar terra, isso não tem tempo marcado. [...] $E$ uma jornada de luta, uma experiência de vida. Geralmente, o que ia acampar era o que não tinha estudo, então o estudo é uma estrada de luta. Hoje já tá indo muita gente da cidade que tem estudo, estão largando a cidade porque estão achando melhor a campanha. [...] O que está acontecendo nessas vilas é a maleza cada vez pior. Antigamente o pessoal vendia os pedacinhos que tinha pros grandes, os grandes iam tomando conta, e depois iam pra cidade. Hoje muitos estão indo acampar, porque na cidade tem que ter estudo, se não tiver estudo tem que bater carteira. Ou uma coisa ou outra tem que fazer. Hoje tanto pros vilarejos quando pros da colônia a saída é ir acampar. (Sr. Juvenal, 56 anos - do assentamento antigo)

Ao conversar com um sem-terra, ele logo contou com riqueza de detalhes o percurso pelo qual passou até conquistar a terra na qual mora. A partir de tal descrição, é possível identificar elementos de inspiração religiosa ou quase-religiosa ${ }^{7}$. A frequência com que se re-

${ }^{7}$ Giumbelli (2002, p.23), ao discutir as inúmeras possibilidades de interpretação da dinâmica reli- 
ferem aos eventos classificados como momentos de "lutas", ao modo como são as ocupações de terras e prédios públicos, às marchas e passeatas, aos protestos etc. indica que tais eventos carregam uma carga ritualística que une dimensões da vida cotidiana e elementos extraordinários. Nessa perspectiva, o ritual expressa-se como intensificação de pensamentos, de linguagens e de situações comuns (Anjos, 2006).

A maior parte das famílias que se engaja no Movimento passa por longos períodos em acampamentos. Ainda que o tempo de permanência seja variável, há situações em que um acampado pode passar mais de cinco anos nessa condição, tempo durante o qual experimentava um modo de vida incerto e nômade. Como adiantado na introdução, a dimensão objetiva desse nomadismo se deve à necessidade de dar visibilidade às suas reivindicações, que somente produzem os efeitos esperados quando não se estagnam em um local. É necessário que suas ações transformem o cotidiano estabelecido e os coloquem no centro das atenções. Por isso, ao acampamento se impõe a necessidade de, a cada período, movimentar-se, migrar de um lugar a outro, ir aonde está o latifúndio e promover ações de impacto. Esse movimento pode significar sair da "beira da faixa", avançar sobre uma fazenda ao lado e, após o despejo, realizado muitas vezes em questão de dias e, por vezes, associado a uma violência psicológica e física, regressar para o mesmo local de onde saíram. No entanto, pode significar, também, deslocamentos a longas distâncias - chegando até $600 \mathrm{~km}$ - em ônibus, carros e dentro da caçamba de caminhões. Além das manifestações na forma de longas marchas que ocorrem a pé. Esses deslocamentos são quase sempre realizados de noite ou de madrugada e de forma inesperada, assim como o são as ocupações das fazendas.

A dimensão subjetiva desse nomadismo pode ser notada pelo percurso subjetivo que essa dimensão objetiva da luta produz em cada indivíduo. Como destacado na entrevista citada anteriormente, trata-se de "uma jornada de luta, uma experiência de vida". É necessário sair do local de origem, no qual deixam as relações ali esta-

giosa atual, sugere essa noção, a partir de outros autores, para designar aqueles grupos que explicitam uma série de características das "religiões", mas que não se assumem como tal. 
belecidas e, em muitos casos, são obrigados a uma divisão de tarefas internamente à família: o marido fica cuidando das poucas posses e a esposa vai acampar ou vice-versa. Ao integrar-se a esse novo grupo social, que se organiza de uma maneira até então desconhecida, um processo de transformação pessoal é iniciado de forma intensa. A adaptação às regras rígidas que são estabelecidas no acampamento; a exigida confiança em suas lideranças que, em certas circunstâncias, propõem ações de risco e de última hora - tendo em vista evitar o vazamento de informações; e a vivência dos conflitos inerentes a esse tipo de organização são exemplos das situações a que não estavam habituados. Todo esse processo, que compõe o cotidiano de tal movimento e passa a ser experimentado por esses novos integrantes, conduz o indivíduo a uma auto-sócio-análise que se constrói a partir desse novo substrato. Inseridos em tal meio social, esses agentes pensam sobre si mesmos e se situam no mundo que os circunda conforme essa nova experiência. São elementos de uma reflexividade que ocorre à medida que se "perde" objetivamente a base social e material em que estavam estabelecidos (Bourdieu, 1995).

Não se trata, obviamente, de uma ruptura com o passado nem da emergência de um novo sujeito autocentrado que coloca em questão toda sua a visão de mundo precedente, reformulando-a conforme esse movimento nômade. A identidade fixa só existe como ideal. Ocorre, na verdade, um entrelaçamento ou uma fusão da constituição subjetiva que o agente carrega consigo com aquilo que passa a experimentar nesse novo percurso. Assim, é a partir das experiências acumuladas ao longo de sua vida que irá pensar acerca de sua nova condição e constituir (disputar) seu novo território.

Nesse processo, a dimensão religiosa pode ser observada na maneira como os assentados formulam e narram a trajetória marcadamente sofrida que enfrentaram até a conquista da "terra prometida" e se referem à força necessária para superar o cansaço, o sofrimento e o desgaste que esse tipo de luta impõe e que deixa muitos companheiros pelo caminho. A crença religiosa aparece como um apoio importante para superar os entraves e para ampliar os horizontes da esperança. Pode-se dizer que seus deslocamentos ganham um 
sentido de peregrinação. Conforme apontado por Durkheim (1989, p. 493), um dos princípios básicos da crença religiosa é "nos fazer agir" e ajudar a viver. "O fiel que comungou com seu deus não é apenas homem que vê verdades novas que o incrédulo ignora: é homem que pode mais. Ele sente em si força maior para suportar as dificuldades da existência e para vencê-las" (Durkheim, 1989, p. 493).

Baseado na descrição de Hernandes (um assentado no assentamento antigo), tracei no mapa a seguir uma rota aproximada dos seus deslocamentos. Nesse percurso, não estão computadas as várias saídas de curta duração para realizarem suas lutas (apenas uma marcha que realizaram a pé de Bagé para Porto Alegre, com cerca de 400 $\mathrm{km})$. As rotas traçadas constituíram a transferência de todo o acampamento. Durante cerca de quatro anos e meio, eles percorreram mais de $2000 \mathrm{~km}$ até alcançarem o destino final. Assim narrou Hernandes:

Nós ficamos quatro anos e meio acampados e nesse período nós fizemos em torno de 22 mobilizações, entre elas, ocupações, caminhadas, fizemos uma de Bagé a Porto Alegre, quinhentos e poucos quilômetros em vinte e poucos dias, ocupações foram várias, muitas com mortes, lá em Bagé morreu um companheiro. Esse grupo participou daquele episódio da Praça da Matriz onde morreu também um brigadiano, morre sem-terra, mas por acaso morreu um brigadiano também, são todos trabalhadores, infelizmente. [...] Então, na nossa trajetória nós conhecemos praticamente o estado todo, na luta pela terra. Nas vinte e poucas mobilizações nós pegamos de norte a sul o estado, na região central, de Cruz Alta, Bagé, Pelotas, Júlio de Castilhos, Não-Me-Toque, Fortaleza dos Lados, Capela de Santana e no final aqui, que foi a última mobilização que nós fizemos na luta pela terra. [...] Então a luta é um pouco isso, a principal forma de luta é a ocupação, acampamento, a caminhada, chamar a atenção da opinião publica, jejum, greve de fome o pessoal fez também na época. [...] A luta de classe é muito evidente, quem tem não quer perder e quem não tem quer conquistar. Nesse tempo ai existe muito conflito. 
Figura 2. Mapa do Rio Grande do Sul e os diversos deslocamentos dos Sem Terra

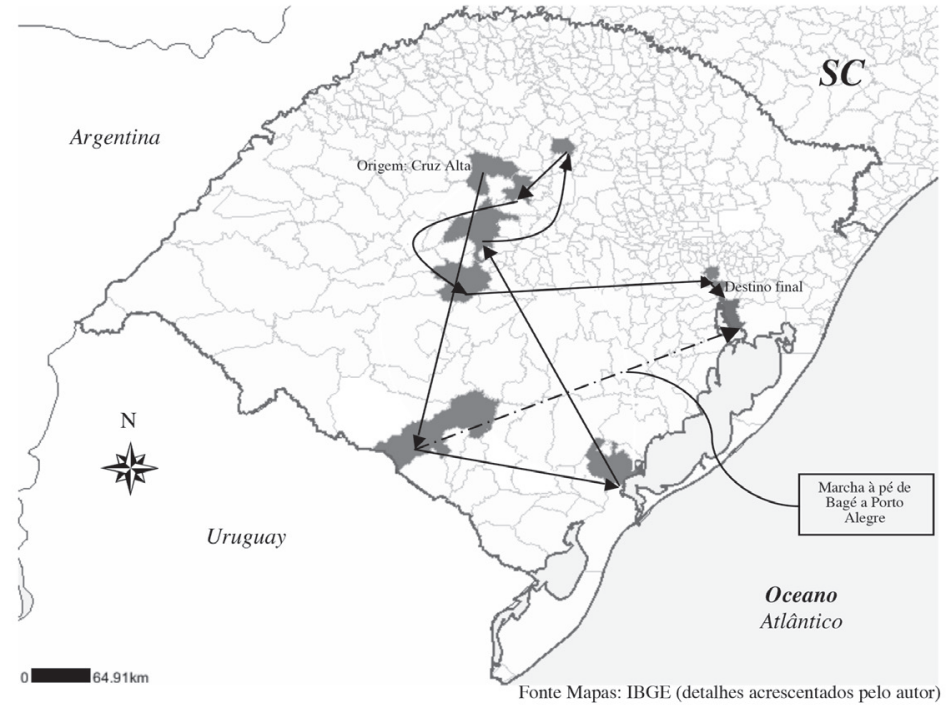

\subsection{A crise da "comunidade"}

C'est Dieu qui commence à donner une identité à différents éléments, et cela commence à faire un monde; et cela commence progressivement à remplacer l'horreur de l'informe, de la totale informité: il y a exigence de structuration et de forme.

(Talal Asad em entrevista a Berthod, 2007)

Ao conquistarem a terra, inicia-se um processo de ordenamento do assentamento, em que a constituição do espaço religioso ocorre de forma concomitante. Essa constituição toma por referência a noção de comunidade como um espaço no qual se realizam as atividades religiosas e sociais de uma dada localidade. Criar e fortalecer a comunidade passa a ser uma ação de grande importância nos assentamentos.

A configuração da comunidade acontece com base em uma delimitação territorial e é materialmente representada por uma estrutura física construída para tal fim. Portanto, o que muitas vezes define uma comunidade é a presença de um salão comunitário e/ou de uma capela na qual as pessoas se reúnem para rezar e festejar. 
Comunidade quer dizer um grupo de quarenta a cinquenta famílias que sejam próximos, que são divididos por uma estrada ou rio, e lá eles formam uma comunidade, uma igreja, um salão de festa. Lá eles chamam a comunidade deles, pra celebrar as conquistas.

\section{Quando faz uma celebração, uma missa...?}

É através dessa comunidade lá, da religião, dá pra dizer. Hoje o nosso assentamento não deixa de ser uma comunidade. Nós vivemos no assentamento, mas também alimentamos esta história, cada assentamento tira um estruturinha lá, um hectare ou dois de terra, organizar um igrejinha, um salão de festa pra celebrar, [...] comemora as conquistas, tem a data sagrada que é quando saiu o assentamento que é uma data onde todo ano fazem festa, celebra as conquistas. Serve pra fazer as reuniões, o local de baile...

Mas o assentamento acaba formando uma comunidade ou varias comunidades?

Uma comunidade, sempre uma comunidade.

Nessa definição, fica evidente a imbricação entre o religioso, o político e o social, que pode se realizar de forma mais ou menos intensa conforme a situação da "comunidade". Frente à dinâmica que se estabelece no assentamento, a comunidade é considerada forte ou fraca conforme o nível de participação das famílias nas atividades ali desenvolvidas ou, sobretudo, a partir da capacidade de realizar atividades frequentes que atribuam um vigor à comunidade. Tais atividades estão sempre relacionadas, em maior ou menor medida, com o religioso. Mesmo as festas e os jogos devem estar conjugados com alguma expressão religiosa.

Nesse sentido, nos dois assentamentos pesquisados, falavase com insistência da fraqueza de suas comunidades, que estava relacionada com a dificuldade de promoverem atividades religiosas. Esse tipo de situação serviu de motivação para se questionar a centralidade do religioso na definição de comunidade. Diante da recorrência com que lamentavam a inexistência da comunidade no assentamento novo, um assentado (que já havia sido seminarista) foi contundente em dizer que eles já eram uma comunidade: "Nós já somos uma comunidade, comunidade não é apenas aquela que reza". 
Trata-se de uma fala que apenas confirmava a regra de que ali o sentido de comunidade estava intrinsecamente relacionado ao religioso e às suas múltiplas realizações. Mas, ainda assim, pode-se dizer que o intrínseco é ambíguo, como percebido nessa situação em que, motivados pelo questionário enviado por alguns freis que realizariam as "Missões Católicas" naquele assentamento, eles elencaram o que era positivo e negativo na comunidade.

O que há de bom na comunidade: formação, aprendizado, vizinhança, amizade, recursos naturais.

Pontos negativos na comunidade: influências externas do capital - prefeitura, INCRA, arrendatários, igrejas, falta de apoio da sociedade, "até o padre não apoia a gente".

Como se percebe, a comunidade assume esse sentido de proteção do "nós" em relação a "eles". Quanto a isso, Tönnies (1973, p.96-97) chama atenção para alguns elementos que caracterizam a comunidade e estabelece um paralelo entre este conceito e o de sociedade. Nesse sentido, comunidade é entendida como a "relação e, consequentemente, a associação", como "uma vida real e orgânica"; sociedade, por sua vez, é compreendida como "uma representação virtual e mecânica". Assim, "Tudo que é confiante, íntimo, que vive exclusivamente junto, é compreendido como a vida em comunidade". Interessante, nesse sentido, foi perceber, na avaliação dos pontos positivos e negativos da comunidades feita por parte desses assentados, a evidência de tal contraponto. No entanto, as críticas aos aspectos relacionados com a cidade indicam menos a ocorrência de um contraponto do que o vigor da interdependência. Isto é, não há, necessariamente, um progresso inexorável da comunidade para a sociedade ou da comunidade para a cidade. A tentativa de estabelecer relações mais estreitas com a paróquia, de serem mais bem aceitos pelos habitantes da cidade e de se colocarem como produtores de alimentos para os citadinos são evidências dessa interdependência ${ }^{8}$.

Voltando à discussão sobre a fraqueza das comunidades, notei que esta era justificada por diferentes aspectos de cada um dos assentamentos. No caso do assentamento antigo, a crise atual con-

${ }^{8}$ Sobre essa relação de interdependência, ver Ernest Gellner (1997). 
trastava-se, conforme os relatos, com períodos precedentes quando experimentaram uma comunidade bastante vigorosa. Este momento de maior participação e animação está relacionado a um período em que viveu entre eles um grupo de freis franciscanos que, no bojo do envolvimento da igreja com as lutas sociais, ali constituíram uma casa na qual se estabeleceu uma instância dessa congregação em que se desenvolvia uma etapa de formação, dentre as várias pelas quais uma pessoa deve passar, para alcançar a condição de frei.

Os jovens que moravam nessa casa aliavam as atividades agrícolas com aquelas de caráter mais estritamente religioso. Algumas pessoas com as quais conversei comentavam a respeito desse período como um momento em que a comunidade era mais vibrante.

Entretanto, no período em que realizei esta pesquisa, era consenso de que faltava maior vitalidade para a comunidade. Relacionado a esse fato, havia um dilema instaurado quanto à transferência da sede da "comunidade" para a área da Cooperativa", já que era neste local estavam concentrados os outros espaços de sociabilidade que reuniam grande parte dos assentados: campo de futebol, bodega, pista de bocha etc. Por ser ali onde os moradores habitavam de forma mais concentrada, o potencial de encontros entre as pessoas era muito maior. E, seguindo a máxima, onde tem gente, vai gente, de fato, não havia lugar mais frequentado no assentamento. Por isso, consideravam que, ao levar a "comunidade" para aquele local, ela se tornaria mais dinâmica. $\mathrm{O}$ que motivava tal ponderação era que a atual localização não facilitava o encontro das pessoas, nem daqueles que pertenciam à Cooperativa nem dos demais assentados. Como salientou uma entrevistada, era um galpão de madeira com aparência de abandono, pois estava afastado do conjunto das famílias que moravam no assentamento. Mesmo quando se promoviam atividades no local da comunidade, a afluência de pessoas era bastante baixa, pois, em grande medida, essas atividades tinham um caráter quase que exclusivamente religioso e, portanto, atraiam apenas aqueles fieis mais assíduos. O comentário a seguir, de uma das assentadas pertencente

\footnotetext{
${ }^{9}$ Desde a origem do assentamento antigo, havia um grupo de famílias (atualmente, ao redor de 30) organizado na forma de uma Cooperativa de Produção Agrícola (CPA).
} 
à Cooperativa, atesta tal situação: "nas missas que tem ali no sábado, na última parece que tinha 5 ou 4 (pessoas)".

Além disso, essas atividades estritamente religiosas "perdiam" público para outras atividades sociais, como foi destacado pelo atual presidente da comunidade, que já fez parte da Cooperativa, mas que, atualmente, apesar de morar na agrovila, trabalha de forma individual associada a outros três assentados:

Hoje tem uma dificuldade em organizá-la (a comunidade) em função do local ela ficou desvinculada das famílias e, a grosso modo, hoje se faz a missa uma vez por mês, a catequese e os velórios. Mas tem uma discussão de trazer a comunidade pra cá pra cima, pra agrovila, porque facilita pros cuidados, pra organização. [...] A gente tava pensando em construir uma igreja e ter outro espaço de lazer. Ate porque lá no espaço onde existe não tem como proporcionar lazer e a comunidade não vive só de missa, eu acho que tem que ter tudo isso, é um conjunto.

Ao considerarem a transferência da "comunidade" para a agrovila, local no qual ocorriam várias outras atividades sociais, estavam projetando que o potencial de assistência aumentaria. Esse aumento poderia ser verificado ao menos entre aqueles do grupo cooperativado, pois se aliariam as atividades de caráter evidentemente social com aquelas de caráter especificamente religioso. No entanto, essa transferência poderia agudizar a tensa relação que havia entre os membros da cooperativa e os demais assentados. Portanto, anunciava-se um ajuste bastante delicado entre um espaço religioso, que deveria ser universal, e um espaço coletivo, porém "privado", no qual se condensava uma enorme carga política. O Frei Carlos ${ }^{10}$ era categoricamente contra essa ideia: "Levar a comunidade para a cooperativa seria uma grande burrice, seria criar duas comunidades, uma da Cooperativa, perde o valor da comunidade que é o de agregar e não dividir. Eu sempre fui contra essa questão".

De todas as formas, o que é notório nesse assentamento é a sua fragmentação, que Dona Eva define em linhas gerais:

\footnotetext{
${ }^{10} \mathrm{Um}$ dos religiosos fundadores da casa de formação para freis que existiu no assentamento.
} 
O assentamento se dividiu, tem o pessoal da Cooperativa que não se mistura muito, tem o pessoal lá de Santa Maria que também ficou dividido pra lá. Se dividiu em três, é a mesma comunidade que se dividiu em três, não tem aquela amizade que deveria ter, ninguém torce por ninguém aqui.

Isso se deve, como Dona Eva aponta, às características que constituem cada um dos grupos reconhecidos no assentamento (definidos, sobretudo, pelo local de origem). Porém, o que é mais evidente é a existência de uma tensão ou talvez de um incômodo percebido na relação dos diversos grupos com a Cooperativa. De fato, os que pertencem à Cooperativa se destacam dos demais assentados, tanto no que se refere às suas conquistas materiais quanto no que se refere ao engajamento político na esquerda, em geral, e no MST, em específico.

Já no assentamento mais novo, as dificuldades encontradas para iniciar a comunidade são constantemente apresentadas como fruto da difícil relação com o pároco responsável por assistir aos fieis daquela localidade e do descaso dos próprios assentados. $\mathrm{O}$ período em que estive visitando esse assentamento coincidiu com um momento em que se dava início aos preparativos para as Missões Católicas. Como apontado anteriormente, cada grupo de assentados (que naquele assentamento eram referidos como "bolsões") deveria realizar a aplicação de um breve questionário proposto pelos frades responsáveis pelas Missões. As questões desse questionário consistiam em traçar um breve perfil religioso do assentamento e sondar as expectativas em relação àquelas Missões. Em duas das três reuniões de que participei, a discussão principal girou em torno do descaso do padre em relação aos assentados, e a principal expectativa era de que as Missões contribuíssem para a formação da comunidade. Várias pessoas com as quais conversei disseram que não entendiam o porquê de o padre tratá-los com tanto descaso. Alguns diziam, inclusive, que estavam pensando em "virar crente" caso continuasse aquela situação.

A permeabilidade do assentamento novo às outras denominações religiosas aumentava à medida que se sentiam desamparados pelos funcionários eclesiais da Igreja Católica. Como não é conce- 
bível ficar sem religião e sem um atendimento religioso, na ausência de uma religião, experimenta-se outra e, conforme as expectativas se ajustam, pode-se passar a uma efetiva conversão ou mesmo ao estabelecimento de uma adesão esporádica, sem um compromisso rigoroso. No caso em questão, o padre, além de não se aproximar deles, era considerado conservador, e suspeitava-se que não tinha simpatia pelos sem-terra. Nesse sentido, afora a carga de preconceito que recebem cotidianamente do meio externo, do comportamento daquele padre também emanava preconceito, apresentando uma forma de tratá-los dotada de uma dimensão política oposta àquela dos outros agentes religiosos simpáticos e militantes daquela causa.

Como é possível notar, a religião é o cimento entre as pessoas de uma comunidade. Muito além de suas características dogmáticas, o que fica retido pelos fiéis é a vivência em um espaço de união e de sociabilidade. É frequente a referência discursiva a um passado cuja forma de praticar e conceber a religião era vivida de modo comum, e é exatamente esse tipo de referência a um modo de vida experimentado em outra época e lugar que informa o investimento feito na construção de um espaço de sociabilidade perseguido no presente pelos agricultores pesquisados.

Pode ser depreendido, portanto, que as famílias percebem o sentido da sua religiosidade no coletivo, motivo pelo qual a angústia de não conseguirem concretizar e fortalecer as suas comunidades parece se impor com maior força. Tanto as dimensões sociais quanto religiosas ficam fragilizadas diante da fragilidade da comunidade. Nesse sentido, há uma comparação possível com o acampamento e sua estrutura organizativa que consegue atingir o coletivo de forma mais abrangente do que a religião no assentamento. O sentido de comunidade no acampamento, apesar (ou em função) dos rigores impostos à convivência, realiza-se de forma mais "eficiente".

\subsection{O local físico e simbólico para as Celebrações}

Nesse processo de fortalecimento ou constituição da comunidade, uma discussão em torno da qual parte dos assentados de am- 
bos os assentamentos estava envolvida dizia respeito à construção de uma capela da igreja católica na área do assentamento que estava destinada ao uso coletivo. Em geral, a área coletiva dos assentamentos coincidia com a antiga sede da fazenda, devido ao fato de normalmente haver ali uma estrutura física que facilitava a ocorrência de atividades de interesse coletivo, como reuniões e festas, e, em alguns casos, servia de escritório para a assistência técnica e/ou para o MST. No assentamento antigo, a principal parte dessa estrutura havia sido destinada ao grupo organizado em Cooperativa e uma parte era reservada para a equipe de assistência técnica do assentamento.

No assentamento novo, toda a área coletiva ocupava dois hectares, em que havia uma área construída (bastante simples) com um pequeno galpão aberto em sua dianteira e ladeado por três salas. $\mathrm{O}$ pequeno galpão era utilizado com frequência para as reuniões da coordenação do assentamento, para as celebrações religiosas (predominantemente católicas), para as festas e para outras diversas reuniões. Uma das salas era utilizada pela assistência técnica e as outras também serviam para pequenas reuniões. O uso dessa estrutura era gerenciado pela coordenação ${ }^{11}$ do assentamento, e, como regra geral, qualquer atividade que ocorresse ali deveria ser previamente submetida à avaliação dessa instância.

A primeira controvérsia quanto ao uso desse espaço ocorreu quando, por ocasião das Missões que seriam realizadas no assentamento, o pároco local solicitou permissão para usar aquele galpão para realizar as missas e os preparativos das atividades religiosas. Naquele assentamento, tratava-se do único espaço adequado para tal fim. Como não havia consenso a respeito do uso para fins religiosos, o assunto foi levado para ser discutido nos bolsões, momento em que foi decidido que seria permitida a realização daquelas atividades religiosas, desde que estendida tal possibilidade para qualquer outra religião.

Mas, com o avanço da constituição da "comunidade" católica, seus integrantes passaram a sentir a necessidade da construção de uma capela que fosse especificamente católica e que servisse às

\footnotetext{
${ }^{11}$ Grupo formado por representantes dos pequenos grupos a partir dos quais o assentamento se organizava politicamente.
} 
suas atividades. Uma das famílias católicas estava disposta a ceder uma pequena parte de seu lote para a construção da capela, mas, como, segundo alguns assentados, não é permitida pelo INCRA a construção de tal empreendimento nas áreas dos lotes, essa possibilidade foi descartada. A única alternativa era a construção na área coletiva. No entanto, havia uma resistência de um pequeno grupo do assentamento - o "grupo dos militantes", conforme designação dos assentados - quanto a tal uso. Esse grupo era composto por assentados que mantinham um vínculo orgânico com o MST, o qual, portanto, se constituía em sua referência interna. "Os militantes" eram favoráveis à construção de uma capela desde que ela tivesse um estatuto ecumênico, ou seja, que concentrasse as atividades de todas as religiões instaladas ou interessadas em se instalar no assentamento. Essa situação estava deixando o grupo que coordenava a "comunidade" um tanto incomodado. Iriam ser necessárias novas discussões para que conquistassem a autorização para construir a capela naquele espaço dedicado ao uso coletivo. Ao mesmo tempo, o grupo católico receava que aquela discussão fosse mais tensa, uma vez que naquele período o INCRA estava intensificando sua fiscalização e pressionando as duas famílias que haviam construído suas igrejas evangélicas em seus lotes. Portanto, o debate que se seguiria deveria contemplar também os interesses dos outros grupos religiosos do assentamento, o que poderia fortalecer a ideia de investir na construção da capela ecumênica para que não se concentrassem várias igrejas no mesmo local.

O comportamento dos militantes de questionar o destino de parte daquele espaço coletivo para uso de grupos religiosos é coerente com a lógica que predomina no acampamento, já que nenhuma religião pode ter privilégio naquele espaço e muito menos colocar em risco a unidade em torno das ações e das atividades cotidianas relacionadas com o Movimento. O diferencial nesse caso era que não estava em questão o formato de celebração que seria adotado. Ninguém nem cogitava que se deveria, também, adotar uma celebração ecumênica como as que eram realizadas no acampamento. O que estava em jogo era definir uma única estrutura física que seria construída na área 
coletiva para evitar que fossem construídas várias igrejas no mesmo local. Nesse aspecto, a principal questão era a incompatibilidade entre as crenças e os ritos religiosos de cada igreja. $\mathrm{O}$ aspecto mais emblemático que sempre foi colocado para exemplificar essa incompatibilidade era a questão dos santos: os evangélicos não admitiriam a permanência de imagens dentro da igreja, e, por sua vez, os católicos consideravam esse tipo de ornamentação fundamental. Enfim, a convivência no mesmo espaço parecia impossível.

No entanto, após as discussões, a posição dos “militantes" foi vencida pela maioria, tendo sido autorizada a construção da capela da Igreja Católica em parte do espaço coletivo do assentamento. Essa possibilidade também estava aberta aos evangélicos, mas tudo indicava que manteriam suas igrejas nos locais onde já estavam, mesmo que em situação presumidamente irregular.

No assentamento antigo, as Igrejas Evangélicas já estavam construídas nos próprios lotes dos fiéis, e a estrutura dedicada às manifestações da Igreja Católica resumia-se a um grande galpão de madeira. Esse espaço servia a celebrações das missas e de outras atividades religiosas e, ao mesmo tempo, à realização das festas da comunidade. Não havia, assim, uma capela especificamente voltada para a realização das atividades estritamente religiosas:

Lá fora ${ }^{12}$ cada comunidade tem uma igreja, aqui não, aqui tem um galpão. Tá abandonado. Se vem dinheiro eu não sei pra onde vai. Não é por falta de dinheiro, são 100 famílias, daria pra construir uma igreja. Ali tem festa, termina uma celebração e tem festa onde acontece tudo, isso não agrada da Deus.

De fato, quando participei da festa da comunidade, notei que havia pelo menos três momentos distintos, que reuniam públicos também distintos. Em um primeiro momento, reuniam-se as pessoas de perfil mais religioso, pois era quando ocorria a celebração religiosa, seja da missa ou, como ocorreu naquele dia, da celebração

\footnotetext{
${ }^{12}$ É comum as pessoas se referirem ao local para além de onde moram como "lá fora". Nesse caso, Dona Eva fazia referência à comunidade de onde saiu para ser assentada onde morava agora.
} 
da palavra, devido à ausência do padre ${ }^{13}$. O espaço e a ornamentação estavam organizados adequadamente para essa celebração: as cadeiras dispostas uma à frente da outra; uma mesa à frente e ao centro coberta com uma toalha de mesa branca, representando o altar; a parede atrás do altar, oposta à grande porta de entrada, estava ornada com a bandeira do MST, uma cruz, cartazes de cartolina com inscrições da bíblia e outros tipos de cartazes com motivos religiosos. $\mathrm{O}$ segundo momento era aquele no qual as pessoas se reuniam para almoçarem, todas distribuídas em grandes mesas. Cada família ou grupo de pessoas, antes de começar a celebração religiosa, comprava um espeto de carne previamente preparado e numerado. Enquanto se desenrolava a celebração, aqueles espetos escolhidos eram assados e, ao final da celebração, eram, juntamente com arroz, aipim e salada, retirados por cada grupo, a partir de uma ficha na qual constava o número do espeto. Aquele cenário, que minutos antes havia sido utilizado para a celebração da "Santa Ceia" - o "alimento da alma" -, era agora rapidamente reordenado para que as pessoas pudessem receber o "alimento do corpo". Os enormes bancos de madeiras eram dispostos de forma perpendicular ao altar - que foi desfeito -, e as várias mesas, em que as pessoas depositavam seus alimentos, trazidas para ocupar todo o espaço do salão. Era um momento que simulava uma grande partilha entre todos, apesar de cada grupo familiar ou de conhecidos demarcar uma parte daquela enorme mesa para limitar o seu espaço de relações e dividir os alimentos comprados. Praticamente não havia intervalo entre esses dois momentos; tudo se organizava de forma bem rápida, e, em pouco tempo, sem muita cerimônia, todos já estavam se alimentando.

Terminado o almoço, nova mudança no cenário. Dessa vez, o intervalo entre um momento e outro era mais longo; as pessoas ficavam um tempo sentadas à mesa conversando antes que se iniciasse o novo arranjo. Todos os bancos e as mesas eram deslocados para as laterais do salão de forma a manter todo o espaço central livre de qualquer obstáculo. A partir desse momento, o cenário transforma-se em um salão de

\footnotetext{
${ }^{13}$ Devido a outros compromissos, o padre compareceu apenas ao final da celebração e fez uma saudação religiosa aos presentes. Também ficou para almoçar ali.
} 
baile, transformando todos em "dançarinos", que assumem a cena. As músicas inicialmente tocadas são aquelas da tradição gaúcha, e a dança ocorre em casal: é o "vaneirão". Com o cair da noite, os jovens tornamse maioria, e o estilo musical se adapta ao novo público.

Como se nota, os públicos variam conforme os vários momentos e cenários da festa. No momento da celebração, estão ali os católicos e aqueles com algum grau de participação religiosa. Durante o almoço, o público que participou da celebração continua ali, mas se nota a presença de outras pessoas que não são tão religiosas e que não participaram da celebração, bem como de pessoas de outras igrejas. Após o almoço, o público que permanece para dançar é diversificadofamílias inteiras, casais e jovens -, mas, dentro do salão, predominam os adultos, já que os jovens, em sua maioria, ficam do lado de fora, reunidos em pequenos grupos. Chegam, então, outras pessoas que não participaram nem da cerimônia religiosa nem do almoço. Ao se aproximar a noite, outros jovens chegam e tornam-se maioria naquele novo cenário. Boa parte dos mais velhos e famílias inteiras se retiram.

A sociabilidade gerada nesse espaço assume diferentes tonalidades ao longo de um mesmo dia. A princípio, trata-se de um ritual cujo principal motivo é o religioso: a festa de São Francisco de Assis, padroeiro da comunidade. Assim, à medida que o tempo passa, os acontecimentos afastam-se daquele momento celebrativo: os rituais vão se afastando do sagrado e se aproximando com maior intensidade do profano, sem, obviamente, chegar à integralidade de um desses pólos. O espaço que, em certo momento, estava fortemente investido de uma dimensão transcendental irá ceder lugar, circunstancialmente, a rituais sociais fundamentalmente imanentes. O sentido religioso da festa perde-se quase que totalmente ao seu final, de modo que as pessoas que chegam para participar já não sabem o que motivou aquela festa nem conhecem o seu significado.

Em algumas comunidades que conheci, havia, além do salão de festas, uma capela que era voltada exclusivamente para atividades estritamente religiosas. Dessa forma, evitavam "profanar" um espaço sagrado com festas e atitudes moralmente questionáveis por alguns. Este era um assunto frequente tanto no assentamento novo quanto no 
antigo: a crítica ao fato de se realizar no mesmo espaço momentos muito distantes simbolicamente (como destacado na citação da fala de D. Eva). Em nenhum desses lugares, havia uma capela com objetivos exclusivamente religiosos, exceto as Igrejas Evangélicas.

Durkheim chama a atenção justamente para essa presença de opostos para definir a ideia de crença. A classificação entre sagrado e profano é constituinte da definição de crença. "Todas as crenças religiosas [...] supõem uma classificação das coisas, reais ou ideais [...] em dois gêneros opostos, designados [...] pelas palavras profano $e$ sagrado" (Durkheim, 1989, p.68, ênfases no original). Ele acentua, ao mesmo tempo, que as coisas sagradas não são, simplesmente, "esses seres pessoais que chamamos deuses ou espíritos; um rochedo, uma árvore, uma fonte, uma pedra, uma peça de madeira, uma casa, enfim, qualquer coisa pode ser sagrada”. Essas análises auxiliam na compreensão do que vem a ser a mística do/no MST. Esta, que é frequentemente trabalhada nos espaços do MST, é como um rito e, como tal, está dotada, em algum grau, desse caráter sagrado. "Os ritos são regras de comportamento que prescrevem como o homem deve se comportar com as coisas sagradas" (Durkheim, 1989, p.72). A mística, como rito, conforma-se pelas regras de comportamento diante do MST e da luta que o Movimento empreende. O MST e a luta são as coisas sagradas que estão no centro desse ritual.

\section{CONCLUSÃO}

Iniciei este artigo demonstrando o caráter nômade da luta dos sem-terra e ilustrando em um mapa do Rio Grande do Sul o longo percurso que experimentaram até conquistarem o assentamento no qual moram atualmente. Nas outras partes do artigo, discuti essa dimensão territorial que se expressa no debate nativo sobre a constituição e a crise da "comunidade" nos diferentes assentamentos.

Ao concentrar meu olhar sobre essas questões que se mostraram muito importantes para aquelas pessoas, pude notar o quanto aquele novo território estava sendo constituído a partir das experiências trazidas dos seus locais de origem e ajustadas às novas ex- 
periências que estavam vivendo. Essa questão pode ser apreendida a partir de outras evidências empíricas; no meu caso, foi a partir da organização ao redor da religião que essa questão ficou mais saliente.

Conforme salientado na introdução, o território constitui-se como tal à medida que podem ser apreendidas as dimensões material e simbólica em um mesmo espaço. Assim, no processo de territorialização que pôde ser observado nos assentamentos pesquisados, fica evidente que a atribuição de sentidos aos diversos espaços se faz a partir de disputas, mais ou menos acirradas, nas quais se evidenciam elementos que rementem a essas dimensões mais funcionais e simbólicas.

A tentativa de ajustar o sentido de comunidade que essas pessoas traziam de suas origens com aquela nova estrutura espacial, dotada de novos personagens e novos sentidos, demonstrava-se um processo tenso e delicado. No assentamento antigo, a comunidade já consolidada enfrentava dificuldades em função dos grupos que ali se estabeleceram divididos, fundamentalmente, pelas suas origens e opções produtivas (produção individual/familiar e produção cooperativada). Também no assentamento novo havia essa clivagem entre os que vinham do interior do estado e estavam mais associados às lides agrícolas e aqueles provenientes da região metropolitana, mais associados ao urbano. No assentamento novo, a constituição da comunidade enfrentava problemas devido às disputas com os "militantes" e com os evangélicos e devido ao descaso do padre local. Aqueles que atuavam para que a comunidade fosse criada estavam sempre tomando como referência aquilo que já haviam experimentado em outras épocas e lugares.

Essas são situações empíricas que explicitam de forma marcante como o espaço vai se dotando de sentido funcional e simbólico e assumindo a feição de território. O território, portanto, vai ganhando forma à medida que os grupos vão disputando os seus sentidos. Como fica evidente, nos assentamentos, vai emergindo uma multiplicidade de territórios. A comunidade católica afirma que todo o assentamento é uma comunidade, mas, dentro daquilo que entendem por comunidade, há várias outras comunidades de sentidos diversos. As comunidades evangélicas, por exemplo, buscam dotar aquele ter- 
ritório das funções e dos sentidos que lhes são próprios. Ao mesmo tempo, contudo, não são territórios que se isolam. Esses múltiplos territórios se interpenetram, no sentido de que seus significados estão influenciados, de alguma forma, por outros significados internos aos assentamentos ou externos a eles.

Nesse novo ambiente que se configura com o assentamento, ao irem para o lote, eles deixam de estar totalmente tutelados pela direção do MST, o que significa uma maior abertura daquele espaço a outros grupos e organizações sociais internos e externos. $\mathrm{O}$ afastamento da condição de acampado dará vazão a uma constituição socialmente mais plural e fará emergir um conjunto de interesses difusos ${ }^{14}$. Tais características criam um ambiente hostil mesmo à presença daqueles apoiadores religiosos que compareciam, sempre que necessário, às atividades do acampamento. No acampamento, tudo convergia para o seu "centro motor" que era o núcleo dirigente ao qual os agentes religiosos estavam aliados - e mesmo confundidos - e pelo qual tinham presença demandada.

Já no assentamento, não há uma organização que catalise essa diversidade difusa de público e de interesses de maneira que consiga congregar a todos ao redor de uma mesma ação, menos ainda no que se refere às questões de caráter religioso ${ }^{15}$. Claro que naquele espaço o seu público ainda reconhece o MST como a organização que lhes integra e, em grande medida, ainda participa das suas instâncias organizativas internas ao assentamento e daquelas mobilizações e protestos com objetivos mais pragmáticos. Mas, ainda assim, trata-se de um espaço onde as pessoas estão mais legitimamente "pulverizadas".

Diante de tal configuração, o assentamento acaba se tornando terra de "missão", ou seja, terra a ser conquistada. Exemplo sintomático disso foi que, durante esta pesquisa, dois grupos religiosos encontravam-se naquele espaço, autodenominados de missionários: um

\footnotetext{
${ }^{14}$ Obviamente que essas características já estavam presentes no acampamento; no entanto, sua manifestação naquele espaço estava, em certa medida, limitada pelas regras e pelo maior poder mobilizador dos seus dirigentes. Além disso, o interesse mobilizador, que era a conquista da terra, suplantava outros interesses difusos e limitava a emergência de grupos e lideranças "menores".

${ }^{15}$ A pluralidade religiosa no acampamento também era bastante rica, ainda que sua manifestação fosse rigorosamente controlada.
} 
grupo de uma pequena igreja evangélica e outro da igreja católica.

Deve ser acentuado, no entanto, que as Missões desenvolvidas pela Igreja Católica (e também pela Evangélica) guardam certa distância desse sentido clássico, que é o de se identificar um território "selvagem" sobre o qual ela deverá exercer o seu poder civilizador/ evangelizador. Digo isso levando em consideração dois aspectos básicos. O primeiro é que o catolicismo é a religião dominante e, nesse sentido, não estava adentrando em um universo inóspito à sua mensagem. Pelo contrário, a expectativa do fortalecimento da Igreja Católica a partir daquelas Missões era bem grande. Mesmo considerando que, das 102 famílias assentadas, conforme o levantamento feito a partir da aplicação daquele questionário (dos próprios missionários católicos), apenas 52 eram católicas ${ }^{16}$, esse número, ainda assim, é bem superior ao das demais denominações e conta com um grupo pequeno, mas atuante, disposto a constituir a comunidade católica.

O segundo aspecto é que, tradicionalmente, as Missões realizadas pela Igreja Católica - após, obviamente, o seu secular estabelecimento e consolidação no território nacional - têm um sentido muito mais festivo e de reafirmação de sua presença, do que um objetivo propriamente civilizador/evangelizador, especialmente naqueles locais afastados das cidades e com precário atendimento pastoral. Trata-se da intensificação de sua presença concentrada em alguns dias. Durante esses dias, realizam-se várias atividades religiosas: batismo, visita aos enfermos, missas, festas, novenas etc. Em várias regiões do país, essa é uma prática comum e muito aguardada pelos moradores. É costume, em comunidades do interior, existirem cruzes instaladas ao lado das capelas nas quais estão inscritas as referências relativas ao período durante o qual as Missões foram realizadas.

Claro que especialmente o assentamento novo assume características peculiares que atribuem também às Missões promovidas

\footnotetext{
${ }^{16}$ Número bem inferior à quantidade estimada de católicos do Rio Grande do Sul, 76,74\%, e do Brasil, 73,77\%, conforme Pierucci (2004). Ainda que esse dado coletado a partir de tais questionários deva ser considerado com cautela devido à sua forma de coleta e aos incidentes já comentados, ele é um tanto ilustrativo de que quantitativamente o catolicismo é relativamente frágil naquele ambiente. Isso sem considerar que tal dado não expressa o aspecto do envolvimento prático com a religião. Nas duas missas de que tive a oportunidade de participar naquele assentamento, o número de famílias presentes foi em torno de dez.
} 
pela Igreja Católica um sentido clássico de conquista de território. Dentre os elementos que competiram nesse sentido, pode ser destacado o fato de o estabelecimento desse assentamento ser recente, $o$ significativo assédio de outras igrejas, especialmente as evangélicas, e a ausência organizada da Igreja Católica. Essas características colocavam aqueles missionários católicos em situação similar a dos evangélicos, pois adentravam em um espaço novo, sem que a tradição religiosa estivesse presente no território, como ocorre em outras localidades rurais. Tudo estava por ser "descoberto"; não havia a mesma familiaridade na acolhida que costuma existir em outros locais. A própria iniciativa de encaminhar aquele questionário era um sinal bem saliente de que estavam diante do desconhecido.

Com tais análises, finalizo este artigo destacando que os assentamentos são espaços bastante diversos e densos de conflitos e disputas entre grupos internos e externos com vistas a atribuir sentidos e funções àquele espaço. Isso fica demonstrado pela discussão em torno da formação e do fortalecimento da comunidade religiosa e em relação à realização das Missões. Olhar esses espaços de forma unitária ou reduzi-los ao domínio das lideranças do MST pode significar a simplificação grosseira de sua complexidade, levando ao entendimento de que são territórios homogêneos quanto aos seus sentidos e às suas funções. O recorte religioso é apenas uma faceta dentre as muitas outras que estão confirmando o estabelecimento de múltiplos territórios que se realizam a partir de suas dinâmicas internas e externas.

\section{REFERÊNCIAS}

BERTHOD, M. A. Penser la terreur, l'horrible et la mort: entretien avec Talal Asad. ethnographiques.org $\mathrm{N}^{\circ} 13$, Junho de 2007. Disponível em: http://www.ethnographiques.org/2007/Berthod.html (consultado em 15 de julho 2008).

BOURDIEU, P. Habitus, illusio y racionalidad. In: BOURDIEU, P.; WACQUANT, L. Respuestas, por una antropologia reflexiva. Mexico: Grijalbo, 1995, pp.79-99.

CABALLERO, I. N. V. "O trabalho no papel": uma etnografia com 
papeleiros. 2008. Dissertação (Mestrado em Antropologia Social) Programa de Pós-Graduação em Antropologia Social, Universidade Federal do Rio de Janeiro, Rio de Janeiro.

CHAVES, C. A. A Marcha Nacional dos Sem-Terra: um estudo sobre a fabricação do social. Rio de Janeiro: Relume Dumará: Nuap/UFRJ, 2000.

COMERFORD, J. Fazendo a luta: sociabilidade, falas e rituais na construção de organizações camponesas. Rio de Janeiro: Relume Dumará, 1999. . Como uma família: sociabilidade, territórios de parentesco e sindicalismo rural. Rio de Janeiro: Relume Dumará, 2003.

DURKHEIM, E. As formas elementares de vida religiosa (o sistema totêmico na Austrália). São Paulo: Paulus, 1989.

GELLNER, E. Antropologia e política: revoluções no bosque sagrado. Rio de Janeiro: Editora Jorge Zahar, 1997.

GIUMBELLI, E. O fim da religião: dilemas da liberdade religiosa no Brasil e na França. São Paulo: Attar Editorial, 2002.

HAESBAERT, R. Dos múltiplos territórios à multiterritorialidade. In: HEIDRICH, A. L. A emergência da multiterritorialidade: a resignificação da relação do humano com o espaço. Porto Alegre: Editora da ULBRA; Editora da UFRGS, 2008.

PIERUCCI, A. F. " "Bye bye, Brasil": o declínio das religiões tradicionais no Censo 2000. Estudos Avançados. Universidade de São Paulo. Instituto de Estudos Avançados. Vol. 18, n. 52, set-dez/2004. São Paulo: IEA, 2004, pp.17-28.

Quirós, J. Cruzando la Sarmiento: una etnografía sobre piqueteros ena la trama social del sur del Gran Buenos Aires. Buenos Aires: Antropofagia, 2006.

TÖNNIES, F. Comunidade e sociedade como entidades típico-ideais. In: FERNANDES, F. (Org.) Comunidade e sociedade: leituras sobre problemas metodológicos e de aplicação. São Paulo: Companhia Editora Nacional/Edusp, 1973, pp.96-116.

THOMPSON, E. P. A formação da classe operária inglesa. Vol. III. A força dos trabalhadores. Rio de Janeiro: Paz e Terra, 1987.

Recebido:30/03/2014.

Aprovado: 02/05/2014. 